\title{
Methodology of Application \\ of the Black Sea Three-Dimensional Temperature and Salinity \\ Fields Reconstructed on the Basis \\ of Altimetry and Scanty Measurements in the Operational Prognostic Model
}

\author{
V.V. Knysh, G.K. Korotaev, P.N. Lishaev \\ Marine Hydrophysical Institute, Russian Academy of Sciences, Sevastopol, \\ Russian Federation \\ e-mail: odop_mhi_nanu@mail.ru
}

\begin{abstract}
The Black Sea condition nowcast and forecast system was developed in Marine Hydrophysical Institute according to MyOcean and MyOcean2 projects and it is still functioning. The developed system includes two modules: hydrophysical, hydrobiological, optical and hydrochemical field nowcast, forecast and reanalysis module and the module of propagation and representation of system products. The module of the sea dynamics nowcast and forecast is the main one in the system as nowcast and forecast hydrophysical fields are used in other modules of the system. Due to paucity of contact measurements of seawater temperature and salinity profiles (certain hydrologic stations and Argo floats), currently these observations are not assimilated in the operative model. The results of prognostic calculations reveal inaccuracies of representation of basin waters mean stratification. A technique for reconstruction and assimilation of three-dimensional temperature and salinity fields in 100-500 m layer (in the conditions simulating operative mode of hydrophysical field nowcast and forecast) is implemented in order to correct the shifts of averaged temperature and salinity modeling profiles in the Black Sea circulation model in the given paper. Three-dimensional temperature and salinity fields are reconstructed for each day of 2012-2013 according to known for these days altimetry level and Argo float measurements accumulated on the horizons of 100-500 m layer over the past 45 days. It is obtained that synoptic structures in the fields of salinity, sea level and current velocity in nowcast and forecast are qualitatively reconstructed quite well. It is revealed that in 0-100 m layer root-mean-square (RMS) deviations between the modeling and observed temperatures are higher than natural variability of the fields. Salinity RMS deviations are lower than its natural variability, except for the layer $45-75 \mathrm{~m}$ which is characterized by the presence of cold intermediate layer. For achieving higher accuracy of nowcast and forecast it is necessary to improve the model of the sea upper layer thermodynamics for the depths from the surface down to $100 \mathrm{~m}$. In addition to assimilation of three-dimensional thermohaline fields in the model, it is necessary to assimilate altimetry level and satellite data on sea surface temperature. It is shown that the proposed method can be effectively used in the operational system of the Black Sea hydrophysical field nowcast and forecast.
\end{abstract}

Keywords: assimilation, three-dimensional fields, operational mode, altimetry, Argo floats, nowcast and forecast accuracy.

DOI: 10.22449/1573-160X-2016-2-46-61

(C) 2016, V.V. Knysh, G.K. Korotaev, P.N. Lishaev

(C) 2016, Physical Oceanography

Introduction. During the period from 2009 to 2014, Marine Hydrophysical Institute (MHI) had been one of the main project executors of the Seventh Framework Program of European Commission MyOcean and MyOcean2 (their objective was to create an integrated pan-European system for the World Ocean and the seas of Europe state nowcasting and forecasting). The Black Sea Monitoring and Forecasting Center (within its framework the system, which is still functioning in the operational mode, was developed and implemented) was established on the MHI basis [1].

The developed system includes two modules: hydrophysical, hydrobiological, optical and hydrochemical field nowcast, forecast and reanalysis module and the 
module of propagation and representation of system products. Nowcasting and forecasting of the sea hydrophysical fields are carried out on the basis of numerical hydrodynamic model [2] using the atmospheric effect data and assimilation of satellite data on surface temperature and sea level anomalies, which are obtained from the relevant interfaces. The mentioned modules operate in an operative mode using a series of subsystems and eventually provide for users an access to four information products. These products are the following: nowcasting and forecasting fields of temperature, salinity, current velocity components, sea level, nitrate and phytoplankton concentrations and also the results of nowcasting of electromagnetic emission absorption coefficient in an optical band of spectrum and reanalysis of temperature, salinity, current velocity vector components and sea level fields.

Sea dynamics nowcasting/forecasting unit plays a decisive role in the system because during the nowcasting and forecasting of hydrobiological and hydrochemical parameters by interdisciplinary three-dimensional model [3] the nowcasting and forecasting fields of temperature, salinity, current velocities as well as the coefficients of vertical turbulent exchange of momentum and vertical turbulent diffusion of heat and salt are used. Due to paucity of contact measurements of seawater temperature and salinity profiles at certain stations and Argo floats $[4,5]$ currently these observations are not assimilated in the operational model. At the same time, the results of prognostic calculations reveal inaccuracies of representation of mean basin waters stratification arising from inadequacy of turbulent exchange processes parameterization, approximate character of initial conditions and errors of atmospheric effect fields [6, 7]. An offset of averaged temperature and salinity model profiles can be adjusted with the assimilation in the model of three-dimensional seawater temperature and salinity fields, which were reconstructed according to unperturbed temperature and salinity profiles (averaged over a certain period) in $100-500 \mathrm{~m}$ layer of the Black Sea deep-water area. Unperturbed temperature and salinity averaged profiles are calculated according to Argo floats probing data. The probing was carried out in proximity to the zero value of altimetry sea level. The method of three-dimensional field reconstruction is based on a notion of predominance of adiabatic processes determining the variability of these fields in a wide range of spatial and temporal scales (this is confirmed by the observations). Further information on this method can be obtained from $[4,5]$.

For increasing nowcast and forecast accuracy, it seems appropriate to develop a special technique that allows assimilating all available hydrological profiles in the operational model of the nowcast/forecast system.

An algorithm (previously proposed for the reanalysis) of assimilation of threedimensional temperature and salinity fields, reconstructed on the basis of joint processing of satellite altimetry and scanty hydrologic observations in the Black Sea, in the present paper is generalized for operational use. Software implementation of the algorithm was carried out, and a preliminary numerical experiment with assimilation of Argo floats data obtained in 2012 - 2013 was performed. Joint processing of altimetry observations and Argo floats data over these years, as well as reconstruction of three-dimensional temperature and salinity fields had been carried out in conditions simulating the operational mode. Peculiarities of marine dynamics nowcast and forecast schemes accepted in operational model and in the present paper, are described in the second part of the work. Assessments of accuracy of the Black Sea three-dimensional temperature and salinity fields are represented in the third part of the paper. Physical analysis of PHYSICAL OCEANOGRAPHY NO. 2 (2016) 
nowcasting/forecasting sea fields are represented in the fourth part of the present work.

Peculiarities of marine dynamics nowcast and forecast schemes used in operational model and in the present paper. Nowcasting and forecasting of the Black Sea hydrophysical fields is carried out in the following sequence: at first the nowcast with assimilation of observations over four days (till the current day) are carried out, then the forecast for five days is performed. The results of the sea field reconstruction from the similar cycle, carried out in the previous day, are initial fields for the nowcast. The results of the sea nowcast field reconstruction on a current day are taken as initial fields for the forecast. Nowcast and forecast calculations are carried out according to the MHI model [2]. Forecast fields of atmospheric effect (calculated according to the University of Athens SKIRON model), obtained from ftp-server ftp://ftp.mg.uoa.gr are used as boundary conditions on the sea surface. In operative version of the model turbulent viscosity and diffusion coefficients are determined according to Mellor - Yamada model [8]. An attachment of seawater temperature and salinity measurement data (obtained using Argo floats) into the model allows avoiding halo- and thermocline smearing which can't be eliminated with correction of model salinity and temperature altimetry data. Halo- and thermocline smearing is probably caused by inaccuracy of turbulent diffusion and viscosity parameterizations.

In the present work it is used the same non-linear eddy-resolving model of MHI as in the operational system, but turbulent exchange of momentum and turbulent heat and salt vertical coefficients were found by means of Richardson number [9, 10] using Pacanowski - Philander formula [11] with parameter values given in [7]. The calculations were carried out on a grid with $5 \mathrm{~km}$ uniform horizontal step ( $238 \times 132$ points). Vertically there were used 38 horizons: 2.5 , 5, $10, \ldots, 30,40,50,63,75,88,100,113,125,150,175,200,250,300,400, \ldots$, $2100 \mathrm{~m}$. Time step made up $5 \mathrm{~min}$.

Heat flows, precipitation and the sea surface evaporation data were taken from ERA-Interim atmospheric reanalysis every 12 hours with $0.75 \times 0.75^{\circ}$ spatial resolution. Modulus of tangential wind stress friction vector was determined by $|\vec{\tau}|=C_{d} \rho_{a} V^{2}$ relation where $\rho_{a}$ is an air density; $V$ is a modulus of wind velocity vector at $10 \mathrm{~m}$ height. $C_{d}$ friction coefficients were calculated according to the formulas of [12]. The fields of tangential wind stress friction components were determined with $6 \mathrm{~h}$ interval. Boundary fields of atmospheric effect were linearly interpolated on each numerical model time step.

In the represented numerical calculation an assimilation of daily threedimensional temperature and salinity fields (pre-arranged for 2012 - 2013 period) in the model (at nowcasting stage) was performed. These fields were reconstructed using an original technique $[4,5]$ for the sea deep-water area bounded by $500 \mathrm{~m}$ isobath. The preparation of temperature and salinity fields for the fixed date was carried out considering the known altimetry sea level for this date and measurements, accumulated over the past 45 days. In total, during $2012-2013$ years there were prepared $(366+365) \times 2$ files with temperature and salinity data for assimilation in the model. The assessments of averaged over the horizons monthly average differences between the temperature (salinity) values reconstructed by the original technique and the ones measured using Argo floats were also obtained. Initial time was $00 \mathrm{~h}$, January 1, 2012. The fields of temperature, salinity, sea level and current velocities, calculated in reanalysis over 
1993 - 2012 years with the assimilation in the model [7] of monthly average temperature and salinity profiles of "zero" level gradation (obtained according to measurements of Argo floats [4]), were taken as initial ones. The data on surface temperature satellite measurements and altimetry sea level were not assimilated in the present work.

Assimilation of reconstructed three-dimensional temperature and salinity fields in heat and salt transport - diffusion equations was performed by inclusion of assimilation sources into the right part. With regard to these sources the equations have the following form:

$$
\begin{aligned}
& T_{t}+(u T)_{x}+(v T)_{y}+(w T)_{z}=-\kappa^{H} \nabla^{4} T+\left(\kappa^{T} T_{z}\right)_{z}-\frac{\partial I}{\partial z}+Q_{T}, \\
& S_{t}+(u S)_{x}+(v S)_{y}+(w S)_{z}=-\kappa^{H} \nabla^{4} S+\left(\kappa^{S} S_{z}\right)_{z}+Q_{S},
\end{aligned}
$$

where $T$ is a temperature; $S$ is a salinity; $u, v, w$ are the components of current velocity vector for $0 x, 0 y$ and $0 z$ axes directed to the East, North and downwards; $\kappa^{T}, \kappa^{S}, \kappa^{H}$ are the coefficients of vertical and horizontal turbulent diffusion, respectively; $\quad I(z)=S w r\left[a \exp \left(-z / b_{1}\right)+(1-a) \exp \left(-z / b_{2}\right)\right], \quad S w r-$ is a shortwave radiation on the sea surface, $a, b_{1}, b_{2}$ are empirical constants. Horizontal turbulent diffusion and horizontal turbulent exchange of momentum (with $v^{H}$ coefficient) are parameterized in the model in the form of biharmonic operators. The values of $v^{H}$ and $\kappa^{H}$ coefficients were taken as equal to $5 \times 10^{9}$ and $10^{8} \mathrm{~m}^{4} / \mathrm{s}$, respectively. The functions of intensity of $Q_{T}$ and $Q_{S}$ sources in the right parts of equations have the following form:

$$
\begin{aligned}
Q_{T}(\vec{x}, t) & =\frac{1}{\operatorname{REL}\left[1+\eta_{T}{ }^{2}\left(z, t_{\mathrm{M}}\right)\right]}\left[T^{\mathrm{obs}}(\vec{x}, t)-T(\vec{x}, t)\right], \\
Q_{S}(\vec{x}, t) & =\frac{1}{\operatorname{REL}\left[1+\eta_{S}{ }^{2}\left(z, t_{\mathrm{M}}\right)\right]}\left[S^{\mathrm{obs}}(\vec{x}, t)-S(\vec{x}, t)\right],
\end{aligned}
$$

where REL is a relaxation parameter; $T^{\mathrm{obs}}(\vec{x}, t), S^{\mathrm{obs}}(\vec{x}, t)$ are temperature and salinity reconstructed by the measurements (with regard to altimetry level structures); $T(\vec{x}, t), \quad S(\vec{x}, t)$ are model values of temperature and salinity; $\eta_{T}{ }^{2}\left(z, t_{\mathrm{M}}\right), \eta_{S}{ }^{2}\left(z, t_{\mathrm{M}}\right)$ is a monthly average measure of measurement error [13], which is a relation of monthly average squared difference of temperature and salinity to the monthly average dispersion of natural variability of respective fields; $\vec{x}=(x, y, z)$. During the numerical solution of equations (1), (2) the assimilation sources were considered from the previous time step. Relaxation parameter was equal to 1 day. Relations (3), (4) are true for the case when temperature (salinity) measurement is presented for each point of deep-water grid domain and it is considered to be independent.

It should be noticed that today we have more complex algorithms both of measured temperature and salinity profiles and sea (ocean) level to be assimilated in the model. Different methods of observational data assimilation, including generalized (ensemble) Kalman filter, optimal interpolation method and the method based on application of Fokker-Planck equation, had been considered in [14]. Assimilation of temperature and salinity vertical profiles (measured with Argo 
floats) was carried out in Hybrid Circulation Ocean Model (HYCOM). It revealed the fact that root-mean-square deviation (RMS) of reconstructed temperature and salinity is minimal when using ensemble Kalman filter. Implementation of generalized Kalman filter in nowcast/forecast operative system is hardly possible as it requires high performance computing resources. For the same reason, it is difficult to use the method based on ensemble Kalman filter for assimilation in altimetry model [15]. An interesting technique of forecast error minimization of the Gulf of Mexico level depending on different initial conditions is proposed in the mentioned paper. Perturbation of atmospheric effect fields and boundary conditions leads to the change of small-scale structures in the level field. A statistical method for three-dimensional temperature and salinity field reconstruction on the basis of high correlation of sea level fluctuations and the ones of temperature and salinity fields at different depths is applied in [16]. However, the correlation relationships are reliable when there is a linear dependence between the considered fields. At the same time, temperature and salinity anomalies change non-linearly during the offset of isothermal and isohaline surfaces. We should notice the work [17] where the World Ocean circulation model with variational assimilation of monthly average temperature and salinity climate fields for reconstruction of temperature, salinity, current field annual change as well as heat and salt flows at the ocean surface is represented.

Statistical characteristics of nowcasting/forecasting temperature and salinity field accuracy. Comparison of daily average nowcasting/forecasting values of temperature and salinity with direct observations allows us to assess accuracy of their representation. The values, calculated at the points of temperature and salinity grid domain, were interpolated into the points with coordinates of considering hydrologic stations and Argo floats synchronizing them by the time. Deviations between calculated and measured temperature and salinity were determined at each horizon. The given operation was carried out for all the stations and Argo floats situated (in 2012 - 2013) within the deep-water basin area bounded by $500 \mathrm{~m}$ isobaths. It should be pointed out that assimilation of measurement data was carried out from $100 \mathrm{~m}$ horizon. Formation of thermohaline fields in 0 - 100 layer is to a greater extend determined by the quality of model and atmospheric effect fields. Root-mean-square deviations between calculated and measured temperature and salinity values, as well as natural deviations of temperature $\left(\sigma_{T}\right)$ and salinity $\left(\sigma_{S}\right)$, are represented in Tables 1,2 as an example. It follows from Table 1 that nowcast temperature and salinity RMS deviation maximum values were obtained in $0-75$ and $75-150$ m layers, respectively; RMS deviation of temperature is greater than the variability (assessed by nowcast) of this field. These facts testify that the model reproduce the sea upper layer hydrodynamics inaccurately. At the same time, the dispersion of salinity field variability, calculated according to nowcast, exceeds the RMS deviation except 300 - 600 m layer.

The change of root-mean-square deviations and natural variability of nowcast temperature and salinity fields (assessed at the horizons) allows us to define the nature of the profile statistical parameters more accurate (Fig. 1). RMS deviation of temperature exceeds natural variability and it is close to the [18] data. In [18] the altimetry was assimilated in the model and calculation results were compared to the temperature and salinity measurement data obtained during four large-scale hydrologic survey. Natural variability of salinity appeared to be lesser than its RMS deviation only in 45 - 75 m layer which is characterized by the presence of 
cold intermediate layer (CIL). As illustrated below, the temperature and salinity model fields in this layer are somewhat smoothed.

T a b le 1

Root-mean-square deviations and natural variability of temperature and salinity nowcast fields assessed in the sea layers for $2012-2013$

\begin{tabular}{c|c|c|c|c}
\hline Layer, m & $\begin{array}{c}\text { RMS deviation of } \\
\text { temperature, }{ }^{\circ} \mathrm{C}\end{array}$ & $\begin{array}{c}\sigma_{T} \\
\text { of temperature, }{ }^{\circ} \mathrm{C}\end{array}$ & $\begin{array}{c}\text { RMS deviation of } \\
\text { salinity, \%o }\end{array}$ & $\begin{array}{c}\sigma_{S} \text { of salinity, } \\
\% \text { o }\end{array}$ \\
\hline $0-75$ & 1.935 & 0.899 & 0.306 & 0.489 \\
$75-150$ & 0.198 & 0.162 & 0.352 & 0.427 \\
$150-300$ & 0.029 & 0.025 & 0.079 & 0.080 \\
$300-600$ & 0.012 & 0.005 & 0.022 & 0.020 \\
\hline
\end{tabular}

T a b l e 2

Root-mean-square deviations and natural variability of temperature and salinity forecast fields assessed in the sea layers for $2012-2013$

\begin{tabular}{c|c|c|c|c}
\hline Layer, $\mathrm{m}$ & $\begin{array}{c}\text { RMS deviation of } \\
\text { temperature, }{ }^{\circ} \mathrm{C}\end{array}$ & $\begin{array}{c}\sigma_{T} \text { of } \\
\text { temperature, }{ }^{\circ} \mathrm{C}\end{array}$ & $\begin{array}{c}\text { RMS deviation } \\
\text { of salinity, \%o }\end{array}$ & $\sigma_{S}$ of salinity, \%o \\
\hline $0-75$ & 1.925 & 0.899 & 0.306 & 0.489 \\
$75-150$ & 0.201 & 0.162 & 0.359 & 0.428 \\
$150-300$ & 0.029 & 0.025 & 0.081 & 0.080 \\
$300-600$ & 0.012 & 0.005 & 0.022 & 0.021 \\
\hline
\end{tabular}

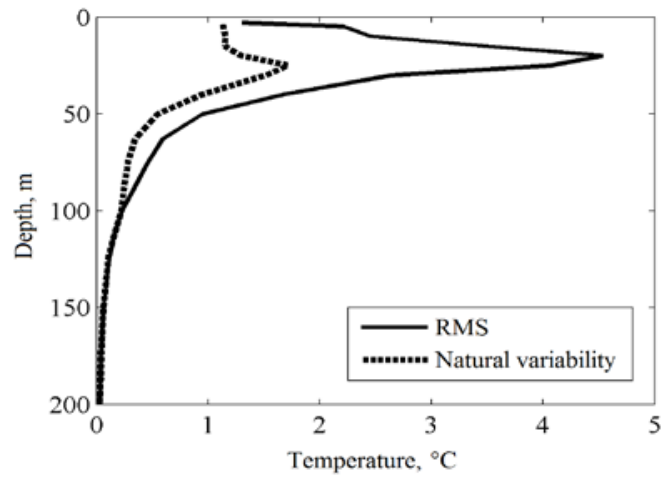

$a$

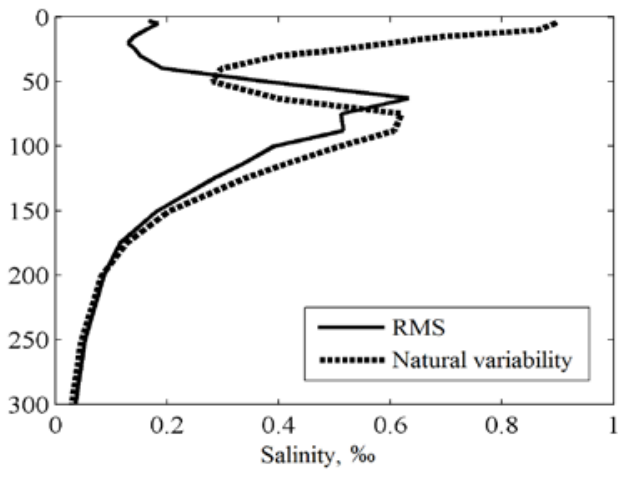

$b$

Fig. 1. Root-mean-square deviations and natural variability of nowcast fields of temperature $\left(\sigma_{T}\right)-$ $a$ and salinity $\left(\sigma_{S}\right)-b$ assessed by the deep-water part of the sea for $2012-2013$

Peculiarities of temperature and salinity forecast field RMS deviation values by the layers (Table 2) and horizons (Fig. 2) are the same as for nowcast fields (represented above). It is indicative that temperature and salinity field RMS deviations assessed by nowcast calculations (Table 1) appeared to be lesser (except $0-75 \mathrm{~m}$ layer) than according to forecasts for the fifth day, in spite of the fact that 
ERA-Interim atmospheric effect fields are not the forecast ones (unlike the SKIRON fields).
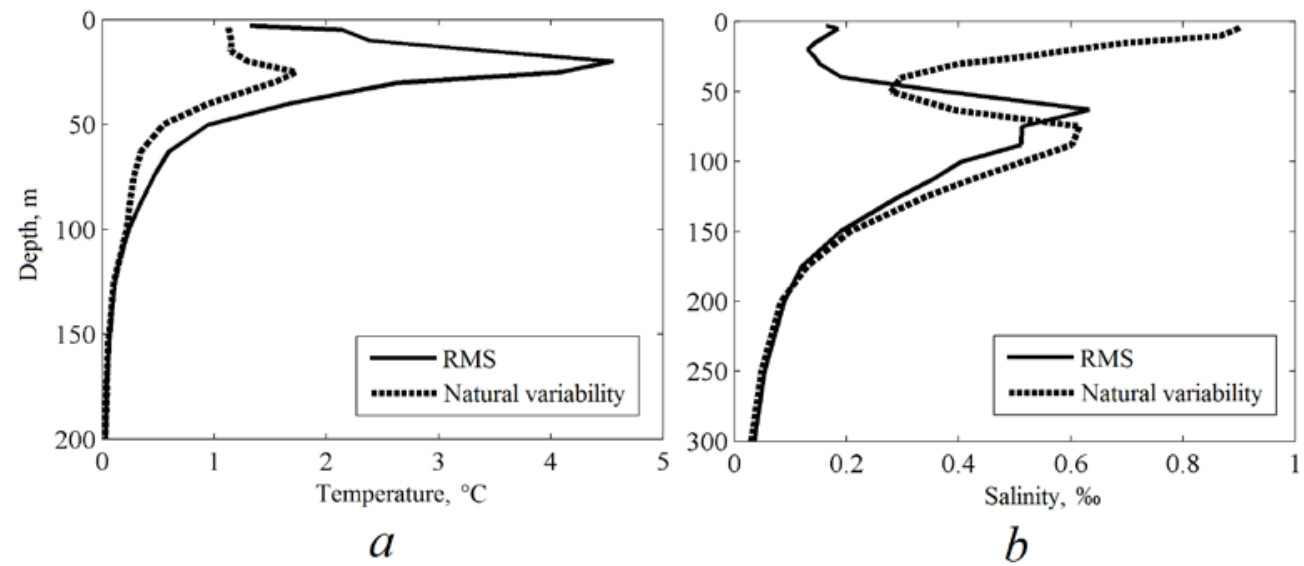

Fig. 2. Root-mean-square deviations and natural variability of forecast fields of temperature $\left(\sigma_{T}\right)-a$ and salinity $\left(\sigma_{S}\right)-b$ assessed by the deep-water part of the sea for $2012-2013$

Comparison of natural variability and RMS deviations of temperature and salinity nowcast/forecast fields allows us to draw a conclusion that it is expedient to assimilate satellite observations of sea surface temperature in order to improve the nowcast/forecast accuracy in surface layer. Also it is necessary to perform additional studies aimed to improve the model of the sea upper layer hydrodynamics.

Analysis of nowcast and forecast fields of the sea for 2012 - 2013. A distinctive feature of the fields reconstructed during the numerical experiment is the fact that their formation in the upper $0-100 \mathrm{~m}$ layer is, to a greater extent, determined by the quality of the model and the fields of atmospheric effect, because temperature and salinity fields under assimilation have been reconstructed for the great depths only. At the same time, the effect of three-dimensional fields (assimilated in the model) of thermohaline parameters on the model temperature and salinity becomes noticeable in the layer which is deeper than $100 \mathrm{~m}$.

Sea level is an important integral function of nowcast/forecast fields because it is possible to compare it with the level reconstructed by the altimetry. Reconstruction details are represented in [4]. As follows from Fig. 3, the structures of nowcast and altimetry levels are qualitatively similar. The intensive Black Sea Rim Current (BSRC) is observed on the nowcast level chart in winter of 2012. The known anticyclonic eddies [19] (Kaliakra, Sinop, Kizilirmak, Batumi and Caucasian anticyclonic eddies) could be seen on its right. The complex structure of water circulation is observed seaward of the West coast of the Crimea, and it is due to the presence of Sevastopol anticyclone and a less intensive cyclonic eddy at this area (Fig. 3, $a, b, c$ ). The sea level elevation is characteristic of the northern part of North-Western shelf. Maximum altimetry level difference makes up $40 \mathrm{~cm}$, maximum difference of level, which was reconstructed in the model, $-27 \mathrm{~cm}$. The 
intensity of cyclonic eddies and anticyclonic eddy formation is lesser in nowcast level field. The structures of nowcast and forecast sea levels are rather similar (Fig. 3, a, c). The mentioned peculiarities of differences between nowcast, forecast and altimetry sea levels are also typical for the winter of 2013.
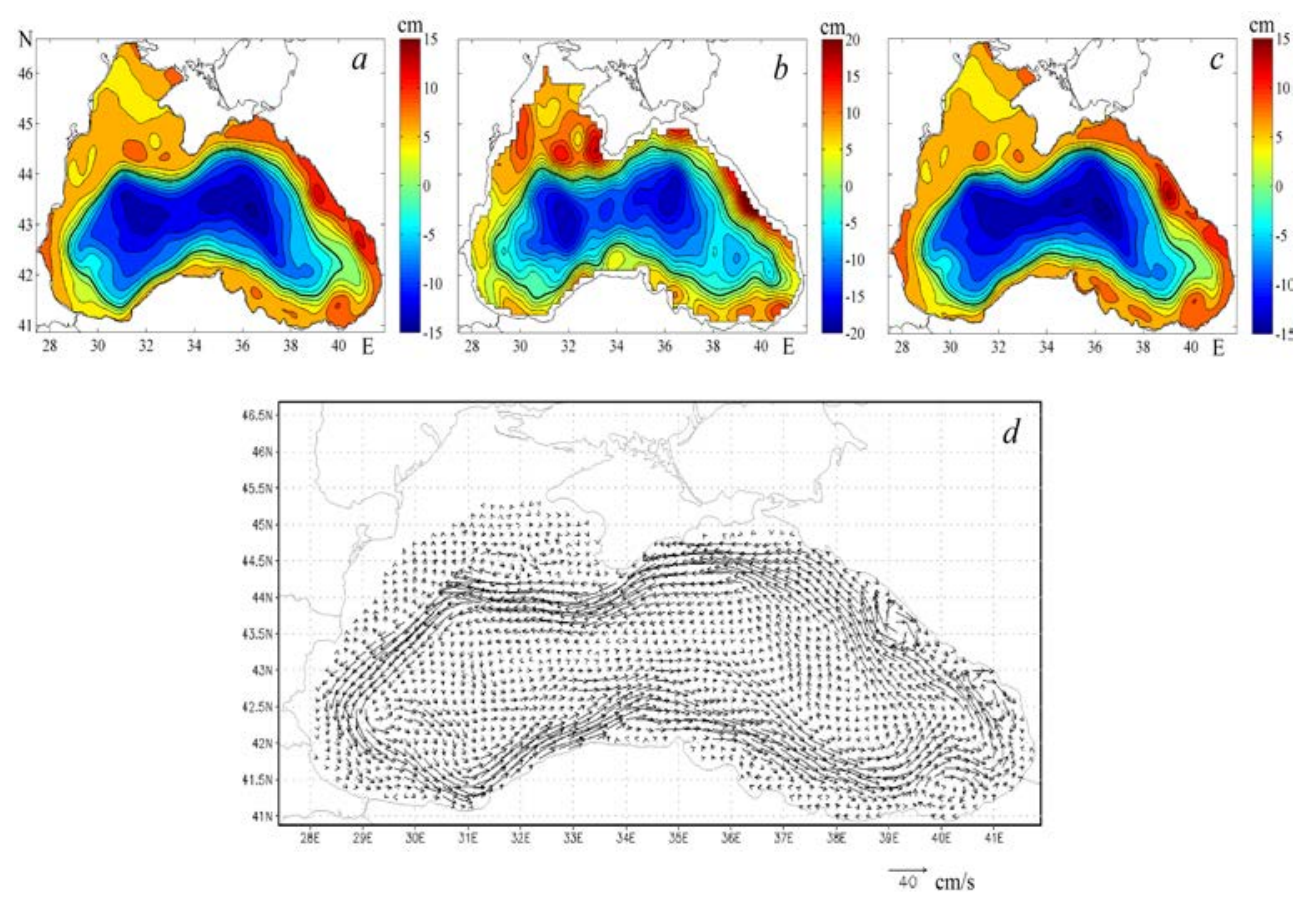

Fig. 3. Nowcast sea level (a), sea level reconstructed by the altimetry data $(b)$, forecast sea level $(c)$ and the currents reconstructed in the model at $50 \mathrm{~m}$ horizon $(d)$ for 20.03.2012

Formation of temperature and salinity fields in $0-100 \mathrm{~m}$ level can be characterized as follows: the effect of three-dimensional salinity fields (assimilating in the model) manifests itself not only in $100-500 \mathrm{~m}$ layer, but also in the layer from 100 to $50 \mathrm{~m}$, inclusive (Fig. 4, $a-c$ ). The structures of salinity fields in the central water area of the sea distinctly characterize Western and Eastern Cyclonic Gyres. However, anticyclonic eddies are much less pronounced on the right from the BSRC at $50 \mathrm{~m}$ horizons and higher than at 63, 75, 88 and $100 \mathrm{~m}$ horizons.

Correction of temperature (assimilated in the model) manifests itself in the layer, higher than $100 \mathrm{~m}$, in somewhat different way. Western and Eastern Cyclonic Gyres are visible only at $88 \mathrm{~m}$ horizon (Fig. 4, d), they are not pronounced at higher horizons (Fig. 4, $e$ ). Cold waters with the temperature below $8^{\circ} \mathrm{C}$ and lesser salinity, which are formed at the North-Western shelf, propagate along the BSRC periphery (Fig. 3, $d$ ) and transform here both temperature and salinity fields and anticyclonic eddies on the right from the BSRC (Fig. 4, c,e). In Fig. 4, $e$ the processes of cold water local intake, which takes place due to winter penetrative convection above the dome-shaped salinity (density) isosurfaces [20, 21] arising from the increase of permanent halocline (pycnocline) in the centers of PHYSICAL OCEANOGRAPHY NO. 2 (2016) 
Eastern and Western Cyclonic Gyres (Fig. 3, a), are manifested. Confirmation of these processes is represented in Fig. 5. We should point out that CIL cold content in 2012 was higher than in 2013.
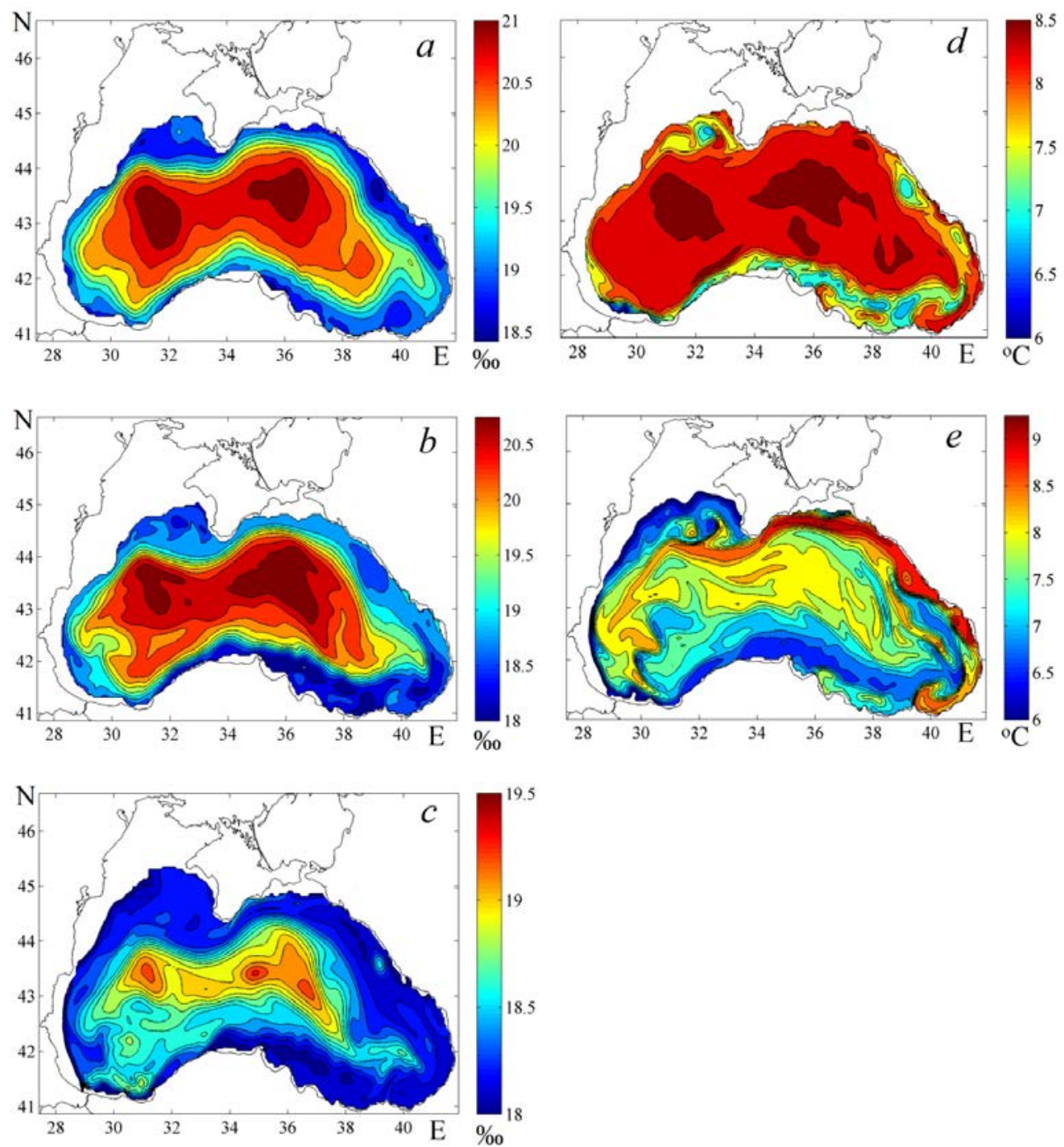

Fig. 4. The charts of salinity at $100 \mathrm{~m}(a), 88 \mathrm{~m}(b), 50 \mathrm{~m}(c)$ horizons and temperature at $88 \mathrm{~m}(d)$, $50 \mathrm{~m}(e)$ horizons for 28.03.2012

The abovementioned peculiarities of formation of temperature and salinity fields in $0-100 \mathrm{~m}$ layer were also observed in winter of 2013. The only difference was that the temperature of CIL renovated waters in 2012 used to be $1-1.5^{\circ} \mathrm{C}$ lower than in 2013.

Anticyclonic eddies as well as horizontal temperature and salinity distributions in this layer are smoothed because the correction of model temperature and salinity in $0-88 \mathrm{~m}$ layer with measurement data was not performed due to their absence. This testifies to disadvantages of the sea upper layer hydrodynamics modeling. The 
difference of nowcast sea level and the intensity of anticyclonic eddies appeared to be underestimated for this reason. To reduce them, it is necessary to assimilate three-dimensional fields of thermohaline parameters in 100 - $500 \mathrm{~m}$ layer in the model along with altimetry level and sea surface temperature [1].
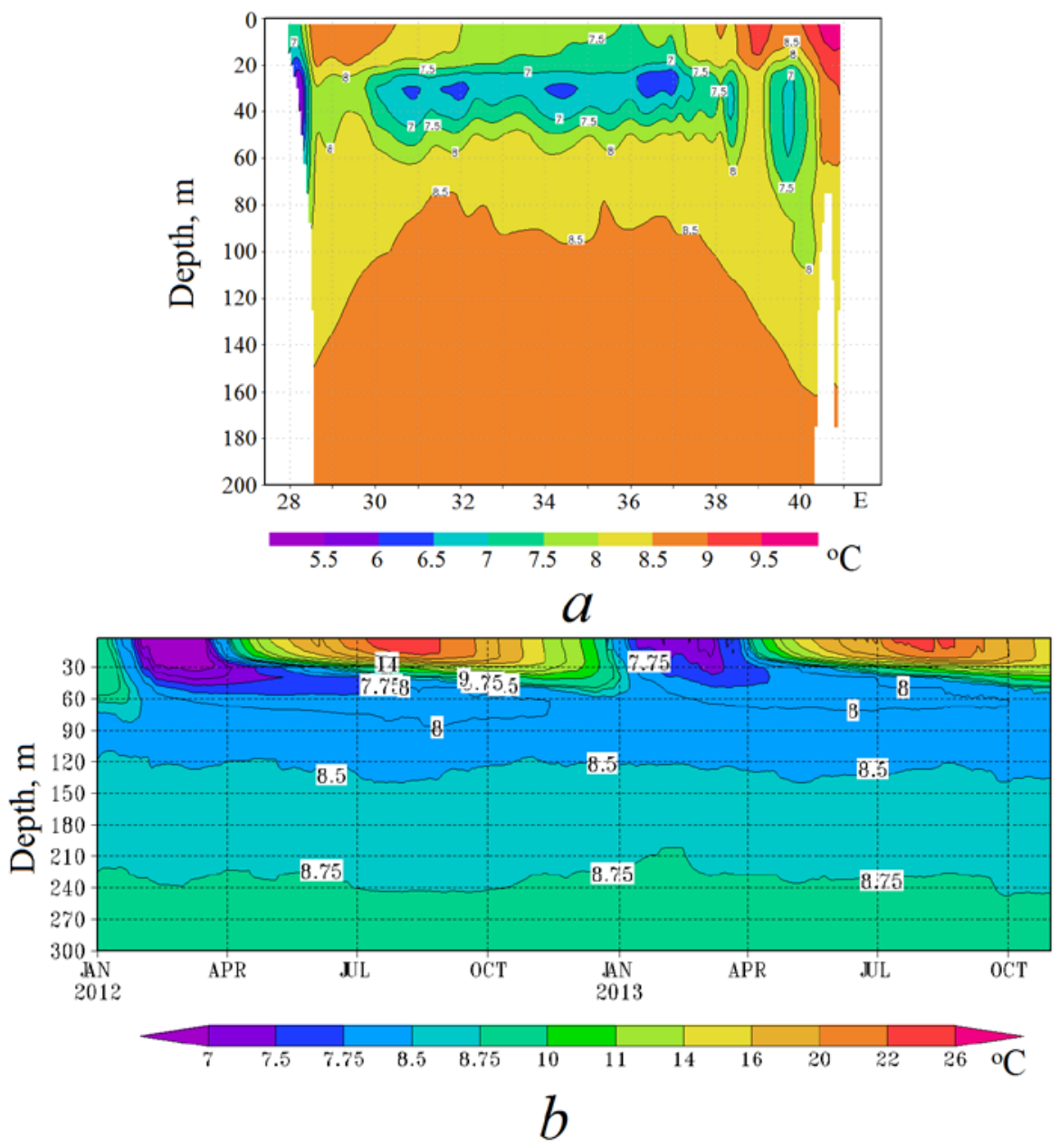

Fig. 5. Temperature section along the $43^{\circ} \mathrm{N}$ for $28.03 .2012(a)$ and the diagram of average temperature at horizons in 0 - 300 layer for $2012-2013(b)$

Anticyclonic eddies as well as horizontal temperature and salinity distributions in this layer are smoothed because the correction of model temperature and salinity in $0-88 \mathrm{~m}$ layer with measurement data was not performed due to their absence. This testifies to disadvantages of the sea upper layer hydrodynamics modeling. The difference of nowcast sea level and the intensity of anticyclonic eddies appeared to be underestimated for this reason. To reduce them, it is necessary to assimilate three-dimensional fields of thermohaline parameters in $100-500 \mathrm{~m}$ layer in the model along with altimetry level and sea surface temperature [1]. 

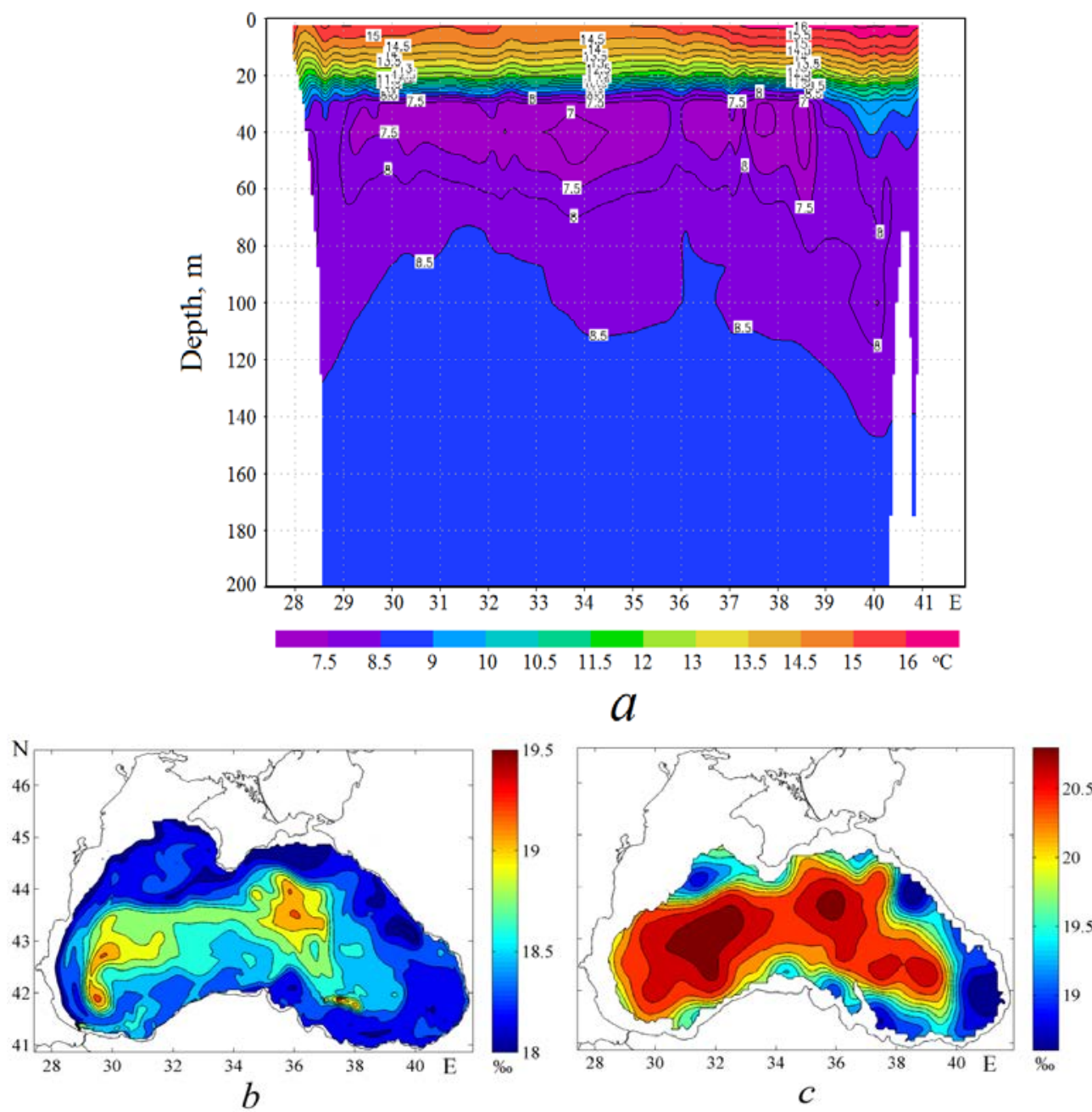

Fig. 6. Temperature section along $43^{\circ} \mathrm{N}(a)$, nowcast salinity field at $50 \mathrm{~m}$ horizon $(b)$ and assimilated in the model salinity field at $100 \mathrm{~m}$ horizon $(c)$ for 9.05 .2012

Now we are to consider the analysis of hydrophysical fields reconstructed in spring of 2012. Spring is characterized by the fact that during the first ten days of April the surface waters warm up to $9^{\circ} \mathrm{C}$. Subsequently, the seasonal thermocline, closing the subsurface cold waters (they form the CIL), is formed (Fig. 6, a). Peculiarities of structures of temperature and salinity nowcast fields in $0-100 \mathrm{~m}$ layer consist in a fact that in spring, in contrast to winter, intensive anticyclones are manifested more clear (Fig. 6, b, c). The salinity field represented in Fig. 6, $c$ is an example of temperature and salinity three-dimensional fields reconstructed by the developed technique [4, 5]. In the structure of this field Western Cyclonic Gyre is significantly intensive than the Eastern one consisting of three cores. Some of eastern anticyclones (the ones located southward of Gelendzhik and Batumi Anticyclone) as well as Sevastopol and Kizilirmak anticyclones in spring are bigger and more intensive than in winter. As a result, the structures of nowcast and altimetry sea levels are qualitatively rather similar (Fig. 7). Maximum level 
difference in nowcast makes up $20 \mathrm{~cm}$, and according to altimetry data it makes up $34 \mathrm{~cm}$. Insufficient difference in nowcast sea level field is apparently related to several assumptions adopted in the technique of temperature and salinity threedimensional field construction. Particularly, it was assumed a linear dependence of the salinity under observation, which belongs to "zero" altimetry level gradation, on all its other gradations (both positive and negative) [5].
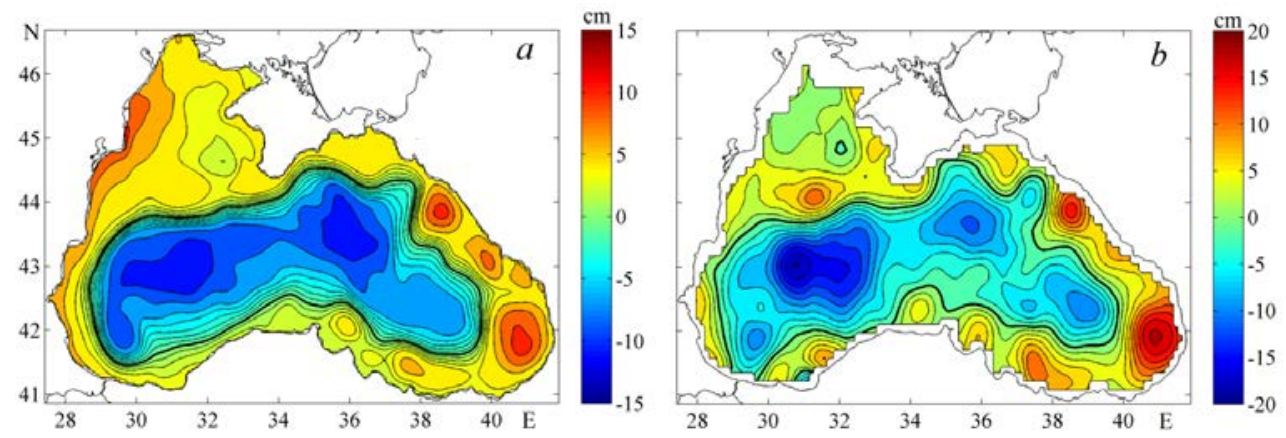

Fig. 7. Sea level for 9.05.2012: nowcast (a) and altimetry (b)

In the reconstructed sea level topography for May 9, 2013 two cyclonic eddies are situated in the inner South-Western area of the BSRC, whereas in altimetry level these eddies are separated and can be observed out of the BSRC. The analysis revealed the fact that the dissimilarity from altimetry level is due to the structures of salinity fields, which have been reconstructed in $0-100 \mathrm{~m}$ layer owing to thermodynamic processes. Sakarya anticyclone, affecting the Southern jet of the BSRC towards the powerful Caucasian anticyclone (Tuapse region), is poorly pronounced in this layer. Sakarya anticyclone intensity was insufficient to interact with Caucasian anticyclone and cut off cyclonic eddies from the inner BSRC limits.

The analysis of daily average sea level altimetry fields indicated that the BSRC was very intensive from January to mid-May 2012. From January to March 2013, the BSRC intensity used to be much lower. The common feature of the considered time periods was the following: in summer (June - August) the periods of both collapse and intensification of the BSRC had been observed.

We should pay attention to the mechanism of the BSRC collapse, being observed in summer. As it can be seen in Fig. $8 a$, such mechanism is a penetration of intensive anticyclonic eddies (Sinop and Crimean (Yalta) eddies) from the BSRC periphery to the central part of sea basin towards each other. Such phenomenon becomes possible in summer-autumn period when the BSRC intensity decreases. It results in the BSRC dismemberment into Western and Eastern separated gyres.

Penetration of anticyclonic eddies into the central part of the sea is also observed in nowcast field of the level (Fig. 8, $b$ ), but it is weaker due to the eddy intensity, and it deforms the BSRC to a lesser extent (Fig. 8, b, c). The eddies interact with the BSRC jets at the places of their formation. Thus, a cyclonic eddy, located in the south-eastern inner part of the BSRC, was isolated owing to such 
interaction of Kizilirmak and Caucasus (southward of Gelendzhik) anticyclones from May 25 to June 14, 2013. It should be pointed out that more intensive interaction of Kizilirmak and Caucasus anticyclones can be observed in altimetry level field. As noted above, the cause for lack of anticyclonic eddy intensity in the nowcast is due to quite inadequate thermodynamics in $0-100 \mathrm{~m}$ layer, where the interacting eddies are poorly pronounced.
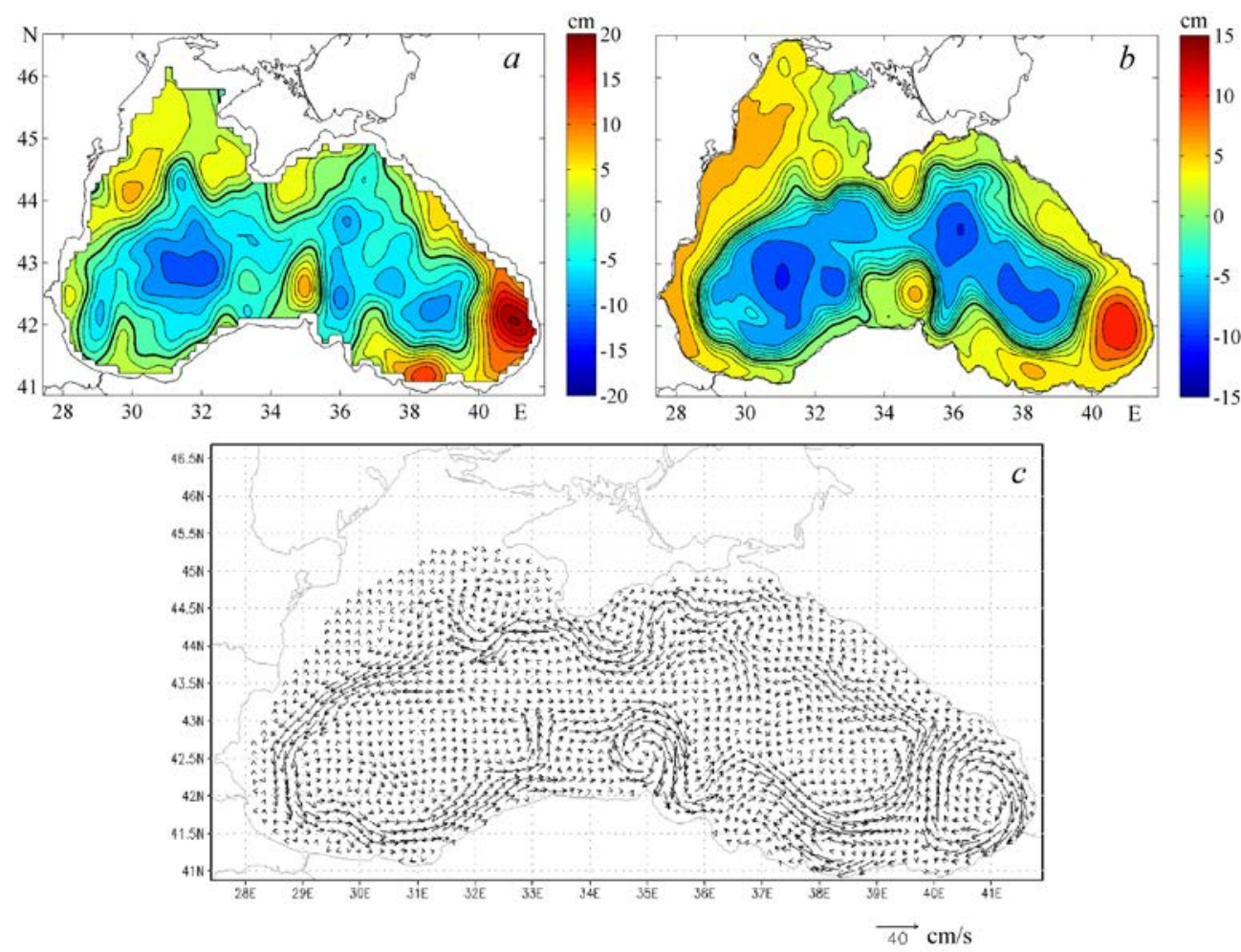

Fig. 8. Altimetry $(a)$ and nowcast $(b)$ sea level; the currents (reconstructed in the model) at $50 \mathrm{~m}$ horizon (c) for 1.07.2012

In September - November 2012 and September - October 2013 the BSRC is almost absent in the altimetry level field. The number of eddies with both positive and negative vorticity increases in the Black Sea basin in this period (Fig. 9, a). Topographies of nowcast and altimetry levels are qualitatively similar (Fig. $9 a, b$ ). Maximum altimetry level difference makes up $32 \mathrm{~cm}$, nowcast level difference $20 \mathrm{~cm}$. It is obvious from Fig. 9, $b$ that in nowcast the Black Sea Rim Current is more pronounced. The BSRC jet meanders and it can be traced well by the water circulation (Fig. 9, c). The analysis has indicated that anticyclonic eddies are poorly pronounced in the structures of temperature and salinity fields (which are located to the right of the BSRC) at 0-100 m layer horizons.

Comparison of sea temperature and salinity nowcast and forecast fields indicates that in $0-100 \mathrm{~m}$ layer they differ insufficiently. In deeper layers the differences become more pronounced. 

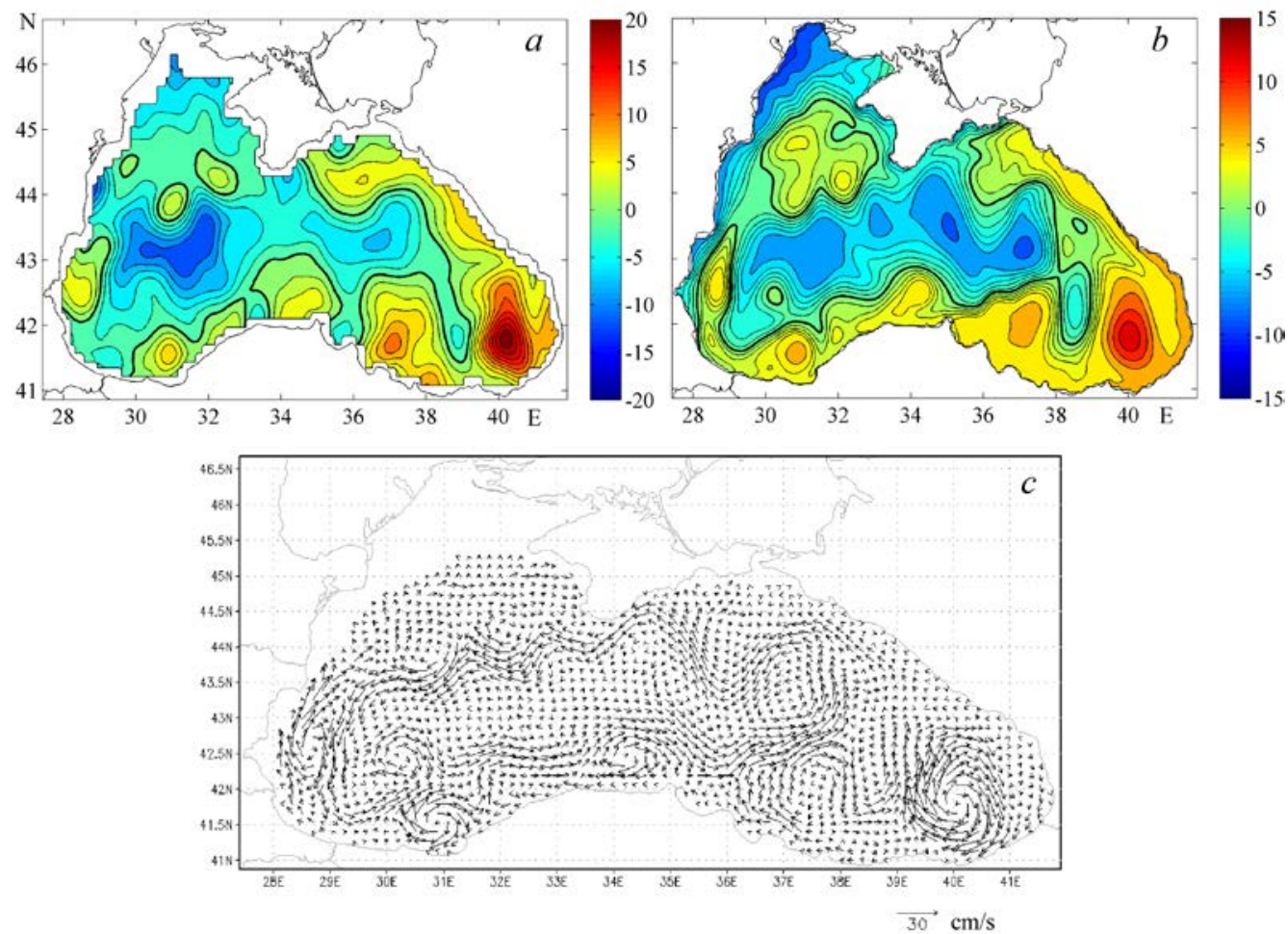

Fig. 9. Altimetry (a) and nowcast (b) sea level; the currents (reconstructed in the model) at $50 \mathrm{~m}$ horizon (c) for 23.09.2013

Conclusion. The results, represented in this paper, demonstrate that technique of temperature and salinity field reconstruction on the basis of scanty measurements involving satellite altimetry $[4,5]$ can be effectively used in operative nowcast/forecast system of the Black Sea hydrophysical fields [1].

The performed numerical experiment (with the assimilation in the Black Sea circulation model of three-dimensional temperature and salinity fields, prepared for the fixed date allowing for the known (for this date) altimetry sea level and measurements, accumulated over the past 45 days, 2012 - 2013, in $100-500$ layer) revealed that synoptic structures in the fields of temperature, salinity, sea level and current velocities in nowcast and forecast are reproduced quite well at qualitative level. Assessment of statistical characteristics of temperature and salinity field nowcast and forecast indicate that RMS deviation of temperature is higher than natural variability in the surficial sea layer. Natural variability is higher than their RMS deviations, except for the 300 - 600 m layer and $45-75$ layer which is characterized by presence of cold intermediate layer. For obtaining higher accuracy of nowcast and forecast it is necessary to improve the sea upper layer hydrodynamic model for the range of depths from the surface down to $100 \mathrm{~m}$. In addition to assimilation of three-dimensional thermohaline fields, altimetry level and sea surface temperature should be also assimilated [1]. 


\section{REFERENCES}

1. Korotaev, G.K., Demyshev, S.G. \& Dorofeev, V.L. [et al.], 2013, “Arhitektura i rezul'taty raboty Mezhdunarodnogo Chernomorskogo centra morskih prognozov, sozdannogo na baze MGI NAN Ukrainy v ramkah proekta Evropejskogo Soyuza "Moj Okean" [Architecture and results of work of the Black Sea Marine Forecast Center established on the basis of MHI NAS of Ukraine within the framework of European Commission project MyOcean”]”, Sevastopol, ECOSI-Gidrofizika, iss. 27, pp. 128-133 (in Russian).

2. Demyshev, S.G., 2012, "Chislennaya model' operativnogo prognoza techeniy $v$ Chernom more [Numerical model of operative forecast of currents in the Black Sea]", Izv. RAN. Fizika atmosfery i okeana, no. 1, pp. 137-149 (in Russian).

3. Dorofeev, V.L., Korotaev, G.K. \& Sukhikh, L.I., 2012, “Modelirovanie evolyutsii ekosistemy Chernogo morya $v$ techenie trekh dekad (1971-2001) [Modeling of the Black Sea ecosystem evolution during three 10-day periods (1971-2001)]”, Morskoy gidrofizicheskiy zhurnal, no. 3, pp. 61-74 (in Russian).

4. Korotaev, G.K., Lishaev, P.N. \& Knysh, V.V., 2015, “Metodika analiza dannykh izmereniy temperatury i solenosti Chernogo morya s ispol'zovaniem dinamicheskogo al'timetricheskogo urovnya [Technique of the Black Sea Temperature and Salinity Measurement Data Analysis Using Dynamic Altimetry Level]”, Morskoy gidrofizicheskiy zhurnal, no. 2, pp. 26-42 (in Russian).

5. Korotaev, G.K., Lishaev, P.N. \& Knysh, V.V., 2016, "Vosstanovlenie trekhmernykh poley solenosti i temperatury Chernogo morya po dannym sputnikovykh al'timetricheskikh izmereniy [Reconstruction of Three-Dimensional Fields of Temperature and Salinity Based on Satellite Altimetry]”, Issledovanie Zemli iz kosmosa, no. 1-2, pp. 199-212 (in Russian).

6. Ratner, Yu.B., Kubryakov, A.I. \& Kholod A.L. [et al.], 2014, “Ispol'zovanie dannykh izmereniy s dreyfuyushchikh buev SVP-BTS i Argo dlya validatsii rezul'tatov prognoza temperatury vody v pribrezhnoy oblasti Chernogo morya [The usage of SVP-BTS and Argo drifting buoy data for validation of water temperature forecast results in the Black Sea coastal area]”, Morskoy gidrofizicheskiy zhurnal, no. 5, pp. 33-48 (in Russian).

7. Lishaev, P.N., Korotaev, G.K. \& Knysh, V.V. [et al.], 2014, “Vosstanovlenie sinopticheskoy izmenchivosti gidrofizicheskikh poley Chernogo morya na osnove reanaliza za 1980-1993 gody [Reconstruction of Mesoscale Variability of the Black Sea Hydrophysical Fields on the Basis of Reanalysis for 1980-1993]”, Morskoy gidrofizicheskiy zhurnal, no. 5, pp. 49-68 (in Russian).

8. Mellor, G.L., Yamada, T., 1982, "Development of a turbulence closure model for geophysical fluid problem”, Rev. Geophys. Space Physics, no. 20, pp. 851-875.

9. Munk, W.H., Anderson, E.R., 1948, “Note on the theory of the thermocline”, J. Mar. Res., no. 7, pp. 276-295.

10. Ibraev, R.A., Trukhchev, D.I., 1998, "Model study of the seasonal variability of the Black Sea circulation”, NATO TU, Black Sea project ecosystem modeling as a management tool for Black Sea, symposium on Scientific results, Dordrecht, Kluwer Academic Publishers, vol. 2, pp. 179-196.

11. Pacanowski, R.C., Philander, S.G.H., 1981, "Parameterization of vertical mixing in numerical models of tropical oceans”, J. Phys. Oceanogr., no. 11, pp. 1443-1451.

12. Hellerman, S., Rosenstein, M., 1983, "Normal monthly wind stress over the world ocean with error estimates”, J. Phys. Oceanogr., no. 13, pp. 1093-1104.

13. Gandin, L.S., Kagan, R.A., 1976, "Statisticheskie metody interpretatsii meteorologicheskikh dannykh [Statistical Methods of Meteorological Data Interpretation]”, Leningrad, Gidrometeoizdat, 357 p. (in Russian).

14. Belyaev, K.P., Tanazhura, K.A.S. \& Tuchkova, N.P., 2012, "Sravnenie metodov usvoeniya dannykh buev "ARGO” v gidrodinamicheskoy modeli okeana [Comparison of assimilation techniques of Argo float data in the ocean hydrodynamic model]”, Okeanologiya, no. 5, pp. 643-653 (in Russian). 
15. Counillon, F., Bertino, L., 2009, "High-resolution ensemble forecasting for the Gulf of Mexico eddies and fronts”, Ocean Dyn., pp. 83-95, doi: 10.1007/s10236-0167-0.

16. Guinehut, S., Dhomps, A.-L. \& Larnicol, G. [et al.], 2012, "High resolution 3-D temperature and salinity fields derived from in situ and satellite observations", Ocean Sci., iss. 5, pp. 845857, doi: 10.5194/os-8-845-2012.

17. Zalesnyy, V.B., Ivchenko, V.O., 2015, "Modelirovanie krupnomasshtabnoy tsirkulyatsii morey i okeanov [Modeling of large-scale circulation of seas and oceans]”, Izv. RAN, Fizika atmosfery i okeana, no. 3, pp. 295-308 (in Russian).

18. Dorofeev, V.L., Korotaev, G.K., 2004, “Assimilyatsiya dannykh sputnikovoy al'timetrii v vikhrerazreshayushchey modeli tsirkulyatsii Chernogo morya [Assimilation of satellite altimetry data in eddy-resolving model of the Black Sea circulation]", Morskoy gidrofizicheskiy zhurnal, no. 1, pp. 52-68 (in Russian).

19. Oguz, T., Malanotte-Rizzoli, P. \& Aubrey, D., 1995, "Wind and thermohaline circulation of the Black Sea driven by yearly mean climatological forcing”, J. Geophys. Res., iss. C4, pp. 6845-6863.

20. Ovchinnikov, I.M., Popov, Yu.I., 1984, “ $K$ voprosu o formirovanii kholodnogo promezhutochnogo sloya $v$ Chernom more [On cold intermediate layer formation in the Black Sea]”, Dokl. AN SSSR, no. 4, pp. 986-989 (in Russian).

21. Ovchinnikov, I.M., Popov, Yu.I., 1987, "Formirovanie kholodnogo promezhutochnogo sloya v Chernom more [Cold intermediate layer formation in the Black Sea]", Okeanologiya, iss. 5, pp. 739-746 (in Russian). 